\title{
Penapisan dan Identifikasi Bakteri Penghasil Enzim Xilanase pada Peuyeum Singkong dengan Metode Penanda Gen 16S rRNA
}

\section{Screening and Identification of Xylanase Enzyme-Producing Bacteria in Peuyeum Cassava with 16 S rRNA Gene Marker method}

\author{
Fenti Fatmawati*, Muhammad Nur Abdillah, Astri Fatmasari, dan Yuni Dwi Mulyaningsih \\ Departemen Farmasi, Sekolah Tinggi Farmasi Bandung, Indonesia \\ Telp / fax : +6222- 7830760 \\ *E-mail: fenti.fatmawati@stfb.ac.id
}

DOI: https://doi.org/10.26874/jkk.v2i1.22

Received: 24 April 2019, Revised: 22 May 2019, Accepted: 23 May 2019, Online: 31 May 2019

\begin{abstract}
Abstrak
Peuyeum merupakan sumber karbohidrat dan merupakan komoditas pertanian yang banyak ditanam di Indonesia. Jenis-jenis polisakarida yang menyusun singkong adalah pati, selulosa dan hemiselulosa dalam bentuk xilan. Xilanase adalah enzim xilanolitik yang dapat menghidrolisis xilan. Bakteri yang memproduksi enzim xilanase telah diisolasi dari peuyeum yang diduga mempengaruhi proses fermentasi. Peuyeum mengandung amilum sehingga merupakan salah satu sumber enzim amilase. Namun belum pernah dilakukan penelitian mengenai skrining enzim xilanase dari peuyeum ini. Tujuan dari penelitian ini adalah untuk mengisolasi bakteri penghasil xilanase pada peuyeum dan mengidentifikasi spesies bakteri ini dengan menganalisis gen 16S rRNA sehingga dapat menjadi sumber baru dalam pencarian enzim. Penelitian ini terdiri dari beberapa tahap yaitu isolasi bakteri, penapisan enzim xilanase, pengujian morfologi, isolasi DNA bakteri, sekuensing, identifikasi bakteri dengan metode pohon filogenetik. Bakteri penghasil enzim xilanase di peuyeum telah berhasil diisolasi. Berdasarkan hasil analisis pohon filogenetik ditemukan bahwa bakteri XF1 memiliki homologi terdekat dengan Bacillus cereus dengan kemiripan 99,84\%.
\end{abstract}

Kata kunci: Bacillus cereus, Filogenetik, Peuyeum, PCR, Xilanase.

\begin{abstract}
Peuyeum comes from cassava which is an agricultural commodity that is widely grown in Indonesia as a food which is source of carbohydrates. The types of polysaccharides that compose cassava are starch, cellulose and hemicellulose in the form of xylan. Xylanase is a xylanolytic enzyme that can hydrolyze xylan. The bacteria producing xylanase enzyme has been isolated from peuyeum which is thought to affect the fermentation process. Peuyeum contains starch so that it is one of the sources of the amylase enzyme. But there has never been a study of peuyeum's xylanase enzyme screening. The purpose of this study was to isolate xylanase-producing bacteria on peuyeum and identify these bacterial species by analyzing the 16S rRNA gene so that it could become a new source in the search for enzymes. This study consisted of several stages, namely bacterial isolation, xylanase enzyme screening, morphological testing, bacterial DNA isolation, sequencing, bacterial identifikation with the phylogenetic tree method. Xylanase enzyme producing bacteria in peuyeum has been successfully isolated. Based on the results of phylogenetic tree analysis it was found that XF1 bacteria had the closest homology to Bacillus cereus with $99 \%$ similarity.
\end{abstract}

Keywords: Bacillus cereus, Phylogenetic, Peuyeum, PCR, Xilanase 


\section{Pendahuluan}

Singkong adalah komoditas pertanian yang banyak ditanam di Indonesia sebagai sumber karbohidrat. Jenis-jenis polisakarida penyusun singkong diantaranya pati, selulosa dan hemiselulosa dalam bentuk xilan. Salah satu makanan olahan dari singkong yang berasal dari Jawa Barat adalah Peuyeum. Peuyeum adalah makanan yang difermentasi dari konsorsium mikroba. Konsorsium mikroba di peuyeum terdiri dari jamur amilolitik, ragi dan bakteri [1].

Peuyeum memiliki aroma, rasa dan tekstur lembut yang khas. Salah satu yang mempengaruhi kualitas peuyeum adalah mikroorganisme pada starter yang digunakan dalam proses fermentasi [2]. Selama proses fermentasi peuyeum, mikroorganisme yang ada akan memetabolisme senyawa nutrisi dalam singkong. Secara umum, jamur akan menghidrolisis pati menjadi gula sederhana yang kemudian akan difermentasi menjadi alkohol dan komponen rasa lainnya oleh ragi [3]. Peuyeum mengandung 3\% alkohol, 40,2\% karbohidrat dan $\mathrm{pH}$ sekitar 4,38 - 4,75. Ragi yang biasa ditemukan dalam konsorsium adalah Sacharomyces cereviceae sedangkan bakteri yang biasanya ditemukan di peuyeum adalah jenis bakteri asam laktat.

Peuyeum yang terbuat dari singkong mengandung pati dan juga xilan. Sampai sekarang, ada banyak penelitian tentang enzim amilase karena peuyeum mengandung pati. Amilase dalam peuyeum berperan dalam memecah pati yang ditemukan dalam singkong menjadi gula sederhana oleh karena itu peuyeum memiliki rasa yang manis. Sampai saat ini belum ada penelitian mengenai penapisan enzim xilanase dari peuyeum singkong. Xilanase sangat bermanfaat dan banyak diaplikasikan dalam industri. Dalam industri kertas xilanase digunakan sebagai agen pemutih karena enzim ini berguna dalam menghilangkan hemiselulosa dalam proses pemutihan. Enzim ini adalah pengganti metode kimia sehingga polusi racun limbah kimia akan dihindari dan lebih murah. Xilanase juga berperan dalam meningkatkan kandungan nutrisi pakan ternak dimana seringkali ditambahkan sebagai campuran pakan untuk meningkatkan pertambahan bobot ayam broiler dan efisiensi konversi pakan. Selain itu xilanase dalam industri makanan, banyak digunakan sebagai pemurni jus, untuk meningkatkan volume roti. Xilanase juga dapat digunakan untuk menghidrolisis xilan (hemiselulosa) menjadi gula xilosa. Gula xilosa banyak digunakan untuk konsumsi penderita diabetes [4].
Adapun tujuan dari penelitian ini adalah untuk mengisolasi bakteri penghasil xilanase dari peuyeum singkong dan kemudian mengidentifikasi bakteri penghasil xilanase tersebut. Hal ini sangat penting untuk memberikan informasi dalam mencari sumber alternatif baru enzim yang banyak digunakan dalam industri.

\section{Metode Penelitian}

\subsection{Bahan dan Alat}

Alat yang digunakan pada penelitian ini adalah gelas kimia, gelas ukur, labu Erlenmeyer, cawan petri, tabung reaksi, mikrotube, pipet mikro Eppendorf, tip pipet mikro berbagai ukuran, autoklav, waterbath (Memmert WNB45), inkubator (Memmert UNB400), microcentrifuge (BOECO M24A), alat PCR (c-100 Thermal Cycler BIORAD), alat elektroforesis. Bahan yang digunakan pada penelitian ini adalah peuyeum, Luria Bertani, Xilan, kongo merah, $\mathrm{NaOCl}$, $\mathrm{NaOH}$, Aquades, $\mathrm{HCl}$, TRIsure, 96\% Etanol, Sodium sitrat, Alkohol 70\%, $\mathrm{NaOH}$, EDTA, primer BactF (5'AGAGTTTGATC(A/C)TGGCTCAG-3') dan Uni B1 (5'-GGTTAC(G/C)TTGTTACGACTT3'), Gel agarosa, TAE Buffer, loading dye, KI, kristal ungu, Fuschin.

\subsection{Isolasi Bakteri}

Sampel peuyeum diambil dari peuyeum yang matang dan siap dikonsumsi. Isolasi bakteri dilakukan dengan teknik E.R Sanders [5]. Bakteri ditumbuhkan pada suhu $37^{\circ} \mathrm{C}$ selama 16 jam dalam media Luria bertani.

\subsection{Penapisan Xilanase}

Koloni tunggal yang diperoleh dari hasil isolasi bakteri pada peuyeum ditanam kembali ke media LB baru. Sebuah koloni tunggal yang diperoleh dari media baru kemudian ditanam kembali di media spesifik (Luria Bertani dan xilan) lalu diinkubasi pada suhu $37^{\circ} \mathrm{C}$ selama 16 jam. Tahap ini dilakukan untuk mengidentifikasi bakteri penghasil xilanase. Bakteri xilanolitik dapat diidentifikasi dengan melihat zona bening setelah penambahan kongo merah [6].

\subsection{Penentuan Morfologi Bakteri}

Bakteri yang teridentifikasi memiliki aktivitas xilanolitik lalu dianalisis morfologinya dengan teknik pewarnaan Gram menggunakan mikroskop Olympus pembesaran 100 kali [7]. 


\subsection{Isolasi DNA bakteri}

Bakteri yang memiliki aktivitas xilanolitik disolasi DNA kromosomnya. Tahap awal yang dilakukan adalah menambahkan reagen TRIsure pada koloni bakteri. Setelah didiamkan selama 5 menit lalu ditambahkan kloroform dan diinkubasi selama 3 menit. Tahap selanjutnya adalah sentrifugasi pada $12.000 \mathrm{rpm}$ selama 15 menit pada $4^{\circ} \mathrm{C}$. Etanol ditambahkan pada pellet kemudian dihomogenisasi dan diinkubasi selama 3 menit. Sentrifugasi dilakukan kembali pada 2000 rpm selama 5 menit pada $4^{\circ} \mathrm{C}$. Pellet ditambahkan dengan $200 \mu \mathrm{g}$ natrium sitrat lalu ditambahkan etanol dan disentrifugasi kembali. Pellet diambil dan dikeringan selama 15 menit. Lalu $\mathrm{NaOH}$ ditambahkan dan disentrifugasi. Supernatan diambil dan $500 \mu \mathrm{g}$ ditambahkan EDTA.

\subsection{Amplifikasi DNA}

Proses amplifikasi DNA dilakukan menggunakan PCR. Amplifikasi menggunakan primer BactF, Uni B1 primer dan mastermix PCR (promega). Kondisi ini dilakukan sebanyak 30 siklus. Suhu dan kondisi yang digunakan pada tahap denaturasi awal $95{ }^{\circ} \mathrm{C}$ selama 3 menit; Annealing $53^{\circ} \mathrm{C}$ selama 30 menit; ekstensi $72^{\circ} \mathrm{C}$ selama 5 menit. Metode ini dijelaskan oleh Feris et al [8].

\subsection{Sekuensing}

Proses sekuensing untuk menentukan urutan nukleotida dilakukan di $1^{\text {st }}$ Base Malaysia menggunakan metode Sanger.

\subsection{Identifikasi Bakteri dengan Pohon Filogenetik}

Urutan nukleotida dari gen 16S rRNA yang diperoleh kemudian dianalisis dengan program BLAST dari NCBI. Kemudian dilakukan analisis filogenetik menggunakan situs web EBI (European Bioinformatics Institute) http://www.ebi.ac.uk.

\section{Hasil dan Diskusi}

Fermentasi dapat didefinisikan sebagai reaksi substrat organik karena aktivitas enzim yang dihasilkan oleh mikroorganisme [9]. Peuyeum adalah salah satu makanan traf. disional singkong yang difermentasi yang banyak dikonsumsi oleh masyarakat Indonesia. Fermentasi peuyeum dipengaruhi oleh mikroorganisme yang ditemukan pada starter yang ditambahkan ke singkong. Starter berisi konsorsium mikroba seperti jamur, ragi, dan bakteri [10]. Penelitian ini dibatasi dengan hanya mengisolasi bakteri dalam peuyeum. Sampel singkong peuyeum dapat dilihat pada Gambar 1.

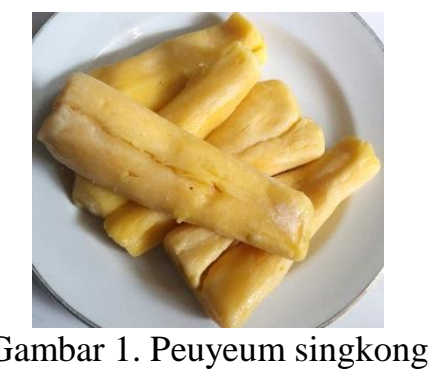

\subsection{Isolasi Bakteri}

Bakteri dari sampel peuyeum yang diisolasi dapat tumbuh setelah inkubasi selama 16 jam pada suhu $37{ }^{\circ} \mathrm{C}$ dimana sebelumnya dilakukan pengenceran bertingkat dengan 4 seri konsentrasi. Serangkaian konsentrasi pengenceran yang dipilih 1000 kali dan 10.000 kali karena jumlah bakteri yang representatif (Gambar 2). Pengenceran dilakukan agar bakteri yang tumbuh tidak terlalu terkonsentrasi sehingga memudahkan proses perhitungan. Pengenceran bertingkat ini meminimalkan jumlah mikroba yang tersuspensi dalam cairan. Penentuan jumlah atau jumlah pengenceran tergantung pada taksiran jumlah mikroba dalam sampel. Pengenceran ini menggunakan $\mathrm{NaCl}$ fisiologis yang berfungsi sebagai larutan isotonik untuk menyesuaikan kondisi tubuh bakteri. Teknik isolasi bakteri yang digunakan dalam penelitian ini adalah prosedur lempeng menyebar. Jumlah total bakteri yang diperoleh adalah 4,47 x $104 \mathrm{CFU} / \mathrm{mL}$.

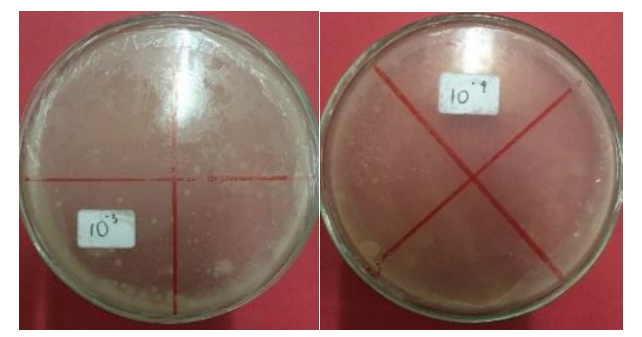

Gambar 2. Pertumbuhan bakteri dari pengenceran 1000 dan 10000 kali

\subsection{Penapisan Xilanase}

Bakteri yang representatif dari pengenceran 1000 kali dan 10.000 kali pada tahap isolasi 
kemudian ditumbuhkan kembali ke media LB baru. Sebanyak 162 koloni tunggal diperoleh dari media baru dan kemudian ditumbuhkan kembali dalam medium spesifik (Luria bertani dan xilan) lalu diinkubasi pada suhu $37^{\circ} \mathrm{C}$ selama 16 jam. Hasil kultivasi dengan medium spesifik menunjukkan adanya 2 bakteri yang memiliki aktivitas xilanolitik dari jumlah keseluruhan koloni yaitu 162 . Hal ini ditandai dengan adanya zona bening yang diproduksi oleh bakteri setelah penambahan kongo merah. Bakteri ini diperoleh dari koloni nomor 61 dan 62 yang kemudian kedua bakteri tersebut dinamakan XF1 dan XF2 (Gambar 3).

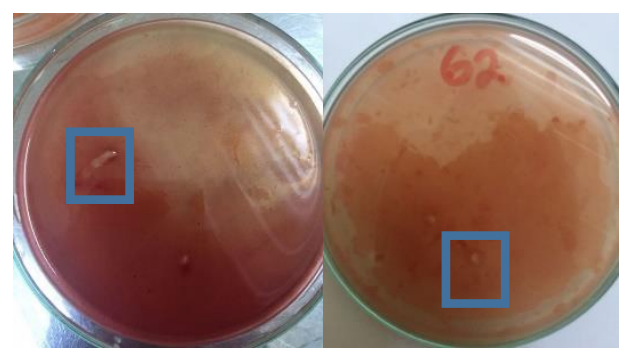

Gambar 3. Penapisan xilanase XF1 dan XF2

\subsection{Penentuan Morfologi Bakteri}

Hanya koloni XF1 yang diuji lebih lanjut karena XF1 dianggap memiliki zona bening yang lebih jelas. XF1 dianalisis morfologinya dengan teknik pewarnaan Gram Hasil pengujian menunjukkan bahwa koloni XF1 adalah kelompok bakteri Gram positif dengan bentuk batang. Ini ditunjukkan oleh hasil pewarnaan Gram yang berwarna ungu jika dilihat dari mikroskop. Bakteri Gram positif masih akan mengikat pewarna kristal ungu sehingga warna berubah menjadi ungu. Sedangkan bakteri Gram negatif akan kehilangan kompleks kristal ungu karena lapisan peptidoglikan pada bakteri Gram negatif lebih tipis sehingga warna akhirnya merah (Gambar 4).

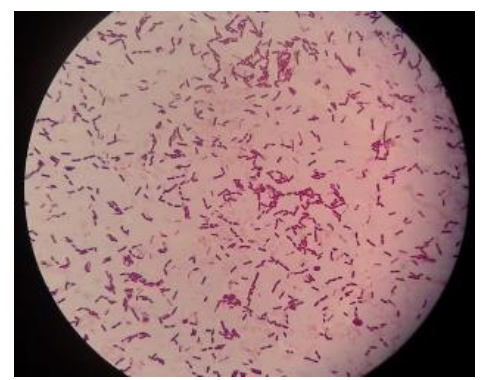

Gambar 4. Hasil pewarnaan gram pada koloni XF1

\subsection{Isolasi DNA Bakteri}

Isolasi DNA kromosom dilakukan pada koloni XF1. DNA yang diisolasi kemudian dielektroforesis menggunakan gel agarosa. Hasil elektroforesis menunjukkan bahwa DNA memiliki ukuran diatas 10.000 bp (Gambar 5).

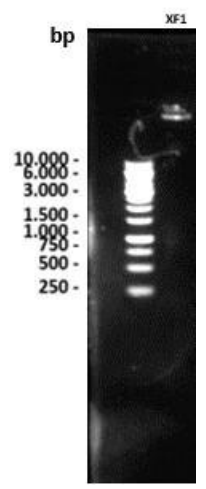

Gambar 5. Elektroforegram hasil PCR DNA kromosom total koloni XF1

\subsection{Amplifikasi DNA}

Proses amplifikasi DNA dilakukan dengan menggunakan alat PCR. Amplifikasi menggunakan 2 buah primer yaitu BactF dan Uni B1 serta reagen PCR (promega). Amplifikasi DNA kromosom dilakukan dengan menggunakan teknik PCR dan hasilnya dielektroforesis dengan agarosa gel. DNA kromosom yang terisolasi digunakan sebagai templat dalam proses PCR. PCR dengan menggunakan penanda genetik 16S rRNA dilakukan dengan tujuan untuk memperkuat gen 16S rRNA. Amplifikasi gen 16S rRNA dilakukan dengan menggunakan primer universal. Urutan gen 16S rRNA telah banyak digunakan untuk menentukan filogeni bakteri dan taksonomi sebagai penanda genetik yang paling umum digunakan karena kehadiran mereka terdapat hampir di semua jenis bakteri. Selain itu, fungsi gen 16S rRNA tidak berubah dari waktu ke waktu [11]. Keberhasilan amplifikasi gen 16S rRNA dapat dilihat dari ukuran DNA yang diperoleh. Dari hasil penelitian ini diperoleh ukuran DNA setelah amplifikasi adalah $\pm 1500 \mathrm{pb}$ (Gambar 6).

Ini menunjukkan bahwa proses amplifikasi telah berhasil dilakukan. Ini karena gen yang diamplifikasi adalah gen $16 \mathrm{~S}$ yang memiliki ukuran sekitar $1500 \mathrm{pb}$ [12]. 


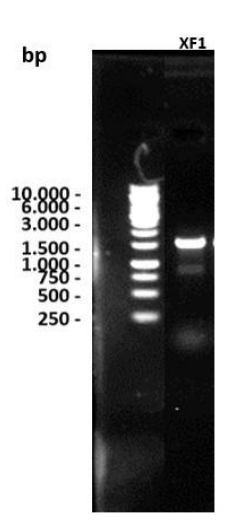

Gambar 6. Elektroforegram hasil PCR fragmen 1.5 $\mathrm{kb}$ dari koloni XF1

\subsection{Sekuensing}

Proses sekuensing untuk menentukan urutan nukleotida dilakukan di $1^{\text {st }}$ Base dengan metode Sanger. Untuk mendapatkan urutan nukleotida, hasil PCR perlu diurutkan menggunakan beberapa primer. Yang utama digunakan adalah Bact $\mathrm{F}$ untuk primer maju dan Uni B untuk primer mundur. Diharapkan dari primer dapat dibaca dengan baik urutan nukleotida dari bakteri target. Berdasarkan hasil dari sekuensing gen 16S rRNA, data pada urutan nukleotida dari primer digunakan. Setiap primer memberikan data tentang urutan nukleotida dalam bentuk elektroforegram dari puncak puncak basa. Puncak dipilih dari puncak tinggi dan tidak menumpuk. Urutan nukleotida yang diperoleh kemudian dianalisis menggunakan program BLAST (www.blast.nbi.nlm.nih.gov/). Program BLAST membandingkan urutan nukleotida yang diproduksi dengan urutan nukleotida di GenBank (www.ncbi.nlm.nih.gov/genbank).

\subsection{Identifikasi Bakteri dengan Pohon Filogenik} Berdasarkan analisis homologi yang diperoleh dari BLAST, dapat dilihat persentase kesamaan bakteri target dengan bakteri lain. Urutan nukleotida gen 16S rRNA dianalisis dengan menggunakan program BLAST dari NCBI dan diperoleh beberapa spesies bakteri yang memiliki kedekatan dengan bakteri XF1 (Gambar 7). Analisis filogenetik ini dinyatakan dalam pohon filogenetik. Pohon filogenetik dibuat untuk menentukan hubungan evolusi antara berbagai spesies. Pohon filogenetik dalam bentuk diagram bercabang dapat dibangun berdasarkan persamaan atau perbedaan sifat fisik atau genetik seperti sekuens DNA, sekuens asam amino (protein), pola pemotongan enzim restriksi dan lainnya. Pohon filogenetik dapat dibangun menggunakan situs web EBI (European Bioinformatics Institute) di http://www.ebi.ac.uk/Tools/clustalw2/.

Berdasarkan hasil analisis pohon filogenetik ditemukan bahwa bakteri XF1 memiliki homologi terdekat dengan Bacillus cereus dengan kemiripan 99,84\% (Gambar 8). Bacillus cereus adalah bakteri gram positif. Bakteri ini umumnya ditemukan di tanah dan makanan. Beberapa strain bakteri ini dapat bermanfaat sebagai probiotik untuk hewan. Dalam penelitian ini, bakteri yang dapat menghasilkan enzim xilanase dari sampel singkong peuyeum berhasil diisolasi. Bakteri ini adalah Bacillus cereus. Bakteri yang biasanya ditemukan di peuyeum singkong menurut Barus dan Wijaya adalah Bacillus subtilis, Lactobacillus plantarum, dan Pseudomonas fragi dengan jumlah $107 \mathrm{cfu} / \mathrm{g}$ [13]. Hasil penjajaran sejumlah bakteri yang diperoleh dari BLAST dapat dilihat pada Gambar 6. Pohon filogenetik dapat dilihat Gambar 7.

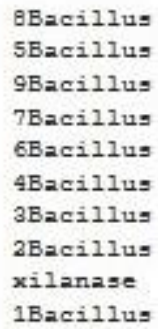

Gambar 7. Hasil pensejajaran sejumlah bakteri 


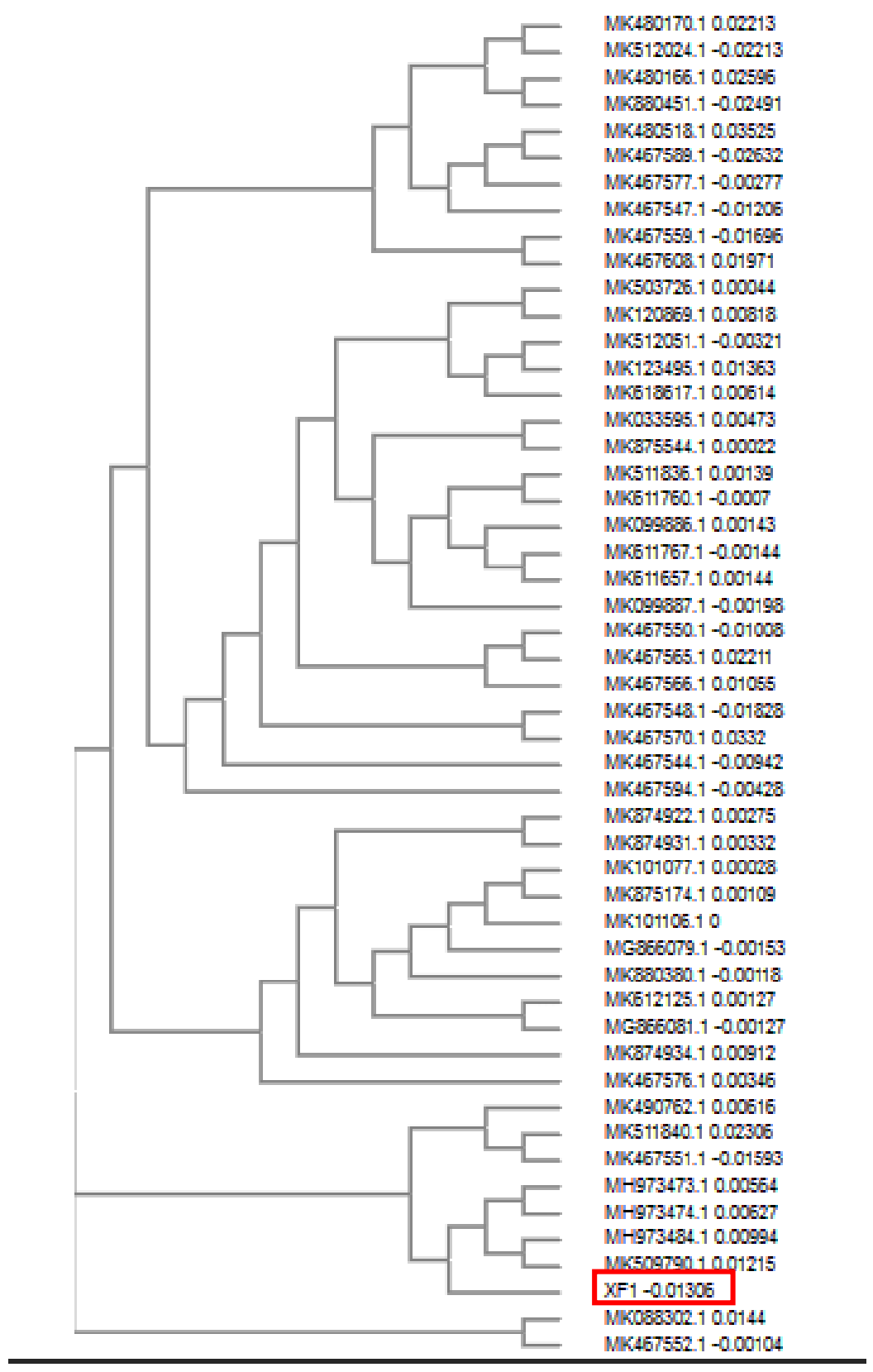

Gambar 8. Pohon filogenetik XF1 (Koloni XF1 pada kotak merah menandakan Xilanase)

\section{Kesimpulan}

Bakteri penghasil enzim xilanase di peuyeum telah berhasil diisolasi. Berdasarkan hasil analisis pohon filogenetik ditemukan bahwa bakteri XF1 memiliki homologi terdekat dengan Bacillus cereus dengan kemiripan 99,8\%.

\section{Daftar Pustaka}

[1] Finalika E, Widjanarko SB. Penetuan nilai maksimum respon rendemen dan gula reduksi brem padat tape ubi kayu (Manihot esculenta). J Pangan dan Agro Ind. 2015. 3(2):670-80.
[2] Barus T, Natalia Wijaya L. Mikrobiota Dominan dan Perannya dalam Cita Rasa Tape Singkong. J Biota. 2011. 16(2). http://dx.doi.org/10.24002/biota.v16i2.119

[3] Djien K. Tape fermentation. Appl Environ Microbiol. 1972. 23:976-8.

[4] Richana N, Irawadi TT, Nur A, Syamsu K. Isolasi Identifikasi Bakteri Penghasil Xilanase serta Karakterisasi Enzimnya. $J$ AgroBiogen. $2016.24(1): 24$. http://dx.doi.org/10.21082/jbio.v4n1.2008.p 24-34

[5] Sanders ER. Aseptic Laboratory Techniques: 
Plating Methods. J Vis Exp. 2012. (63). http://dx.doi.org/10.3791/3064

[6] Samanta AK, Kolte AP, Senani S, Sridhar M, Jayapal N. A simple and efficient diffusion technique for assay of endo $\beta-1,4$-xylanase activity. Brazilian $J$ Microbiol. 2011. 42(4):1349-53.

http://dx.doi.org/10.1590/s151783822011000400016

[7] Wilson C, Lukowicz R, Merchant S, Flynn, Caballero J. Quantitative and Qualitative Assessment Methods for Biofilm Growth: A Mini-review. Res Rev J Eng Technol. 2017. 6(4).

[8] Ferris MJ, Muyzer G, Ward DM. Denaturing Gradient Gel Electrophoresis Profiles of 16S rRNA-Defined Populations Inhabiting a Hot Spring Microbial Mat Community. Appl Environ Microbiol. 1996. 62(2):340-6.

[9] Suprihatin. Teknologi Fermentasi. Unesa Press; 2010.
[10] Gultom GM. Komposisi Mikroorganisme dan Kimia Tape Singkong dan Tape Ketan yang Diproduksi di daerah Bogor. Institut Pertanian Bogor; 2017.

[11] Janda JM, Abbott SL. 16S rRNA Gene Sequencing for Bacterial Identification in the Diagnostic Laboratory: Pluses, Perils, and Pitfalls. J Clin Microbiol. 2007. 45(9):27614. http://dx.doi.org/10.1128/jcm.01228-07

[12] Clarridge JE. Impact of 16S rRNA Gene Sequence Analysis for Identification of Bacteria on Clinical Microbiology and Infectious Diseases. Clin Microbiol Rev. 2004. 17(4):840-62. http://dx.doi.org/10.1128/cmr.17.4.840862.2004

[13] Barus T, Kristiani T, Yulandi A. Diversity of Amylase-Producing Bacillus spp. from "Tape" (Fermented Cassava). HAYATI J $\begin{array}{lll}\text { Biosci. } 2013 . & 20(2): 94-8 .\end{array}$ http://dx.doi.org/10.4308/hjb.20.2.94 